\title{
THE ROLE OF B LYMPHOCYTES AND PRESENCE OF GERMINAL CENTERS IN PATIENTS WITH LOCALIZED PROVOKED VULVODYNIA
}

\author{
LOKALIZE PROVOKE VULVODINI HASTALARINDA B LENFOSITLERIN VE GERMINAL \\ MERKEZ VARLIĞININ ROLÜ
}

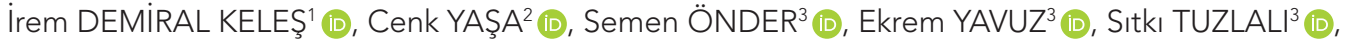 \\ Süleyman Engin AKHAN² (D) \\ 129 Mayis State Hospital, Department of Obstetrics and Gynecology, Ankara, Turkey \\ ${ }^{2}$ Istanbul University, Istanbul Faculty of Medicine, Department of Obstetrics and Gynecology, Istanbul, Turkey \\ ${ }^{3}$ Istanbul University, Istanbul Faculty of Medicine, Department of Pathology, Istanbul, Turkey
}

ORCID IDs of the authors: I.D.K. 0000-0002-0179-2009; C.Y. 0000-0002-7183-1456; S.Ö. 0000-0002-1384-630X;

E.Y. 0000-0002-3166-0648; S.T. 0000-0002-2658-6439; S.E.A. 0000-0002-9086-1060

Cite this article as: Demirel Keles I, Yasa C, Onder S, Yavuz E, Tuzlali S, Akhan SE. The role of B lymphocytes and presence of germinal centers in patients with localized provoked vulvodynia. J Ist Faculty Med 2022;85(1):105-9. doi: 10.26650/IUITFD.903684

\section{ABSTRACT}

Objective: The aim of the study is to assess local immune activation through $B$ lymphocytes density and the presence of germinal centers in the vestibular mucosa of patients with localized provoked vulvodynia (LPV).

Materials and Methods: Vestibulectomy specimens of 29 patients with LPV and colporrhaphy posterior specimens of 20 control women were included in the study. Immunohistochemical staining with CD20 antibodies for B lymphocytes were performed and subsequently, microscopical evaluation for B lymphocytes density and the presence of germinal centers was conducted.

Results: B lymphocyte densities were higher in the vestibular mucosa of patients with LPV compared to control women (87 vs $21, p<0.01)$. The presence of germinal centers was only observed in the specimens of patients with LPV $(0.31$ vs $0, p<0.011)$.

Conclusion: The presence of germinal centers with increased B lymphocyte density underlines a local immune activation in the vestibule of patients with LPV. An abnormal germinal center response can trigger the pathway to the development of autoimmunity through the emergence of an autoreactive $B$ cell clone and autoantibodies. LPV can potentially emerge as an autoimmune disease of the vestibule. More studies are needed to understand the pathophysiology of LPV and its association with autoimmunity.

Keywords: Vulvar vestibulitis, B lymphocytes, germinal center

\section{ÖZET}

Amaç: Bu çalışmadaki amacımız, lokalize provoke vulvodinisi (LPV) olan hastaların vestibular mukozasında, B lenfosit yoğunluğu ve germinal merkez varlığına bakılarak lokal immün aktivasyonun olup olmadığını araştırmaktır.

Gereç ve Yöntem: LPV olup vestibülektomi ameliyatı geçiren 20 hastanın kolporafi posterior ameliyatı olan 20 kontrol hastanın vulvar vestibüler doku kesitleri incelenmiştir. B lenfositini göstermek için kullanılan CD20 antikoru ile yapılan immünohistokimyasal boyamayı takiben mikroskop altında B lenfosit yoğunluğuna ve germinal merkez varlığına bakılmıştır.

Bulgular: Kontrol vakaların kesitleri ile kıyaslandığında, LPV olan hastaların vulvar vestibüler mukoza kesitlerinde B lenfosit yoğunluğu daha yüksek izlenmiştir (LPV hasta 87 vs kontrol hasta 21, $\mathrm{p}<0,01)$. Germinal merkez varlığı sadece LPV olan hastaların vestibüler mukoza kesitlerinde izlenmiştir (LPV hasta 0,31 vs kontrol hasta $0, p<0,011)$.

Sonuç: LPV hastalığında, vestibüler mukozada artmış B lenfosit yoğunluğu ve beraberinde izlenen germinal merkez varlığı, lokal bir immün aktivasyonun olduğunu göstermektedir. Anormal germinal merkez cevabının olması durumunda, otoreaktif B lenfositleri ve bunun sonucunda otoimmün hastalıklar gelişebilmektedir. LPV'nin patofizyolojisinin ve otoimmünite ile ilişkisinin ortaya konmasında daha fazla sayıda çalışmaya ihtiyaç vardır.

Anahtar Kelimeler: Vulvar vestibülit, B lenfosit, germinal merkez

Corresponding author/iletişim kurulacak yazar: irem.demiral@hotmail.fr

Submitted/Başvuru: 04.04.2021 • Revision Requested/Revizyon Talebi: 28.05.2021 •

Last Revision Received/Son Revizyon: 18.06.2021 • Accepted/Kabul: 21.06.2021 • Published Online/Online Yayın: 14.01.2022 


\section{INTRODUCTION}

Vulvar vestibulitis syndrome (VVS), today described as localized provoked vulvodynia (LPV), is a disease showing three prominent characteristics: severe pain triggered by vestibular touch or vaginal entry, vestibular tenderness upon pressure and various degree of vestibular erythema $(1,2)$. With a prevalence up to $15 \%$ in premenopausal women, this disease seriously affects the sexuality and quality of life of patients because the pain can be triggered by any daily condition exercising pressure on the vestibule such as insertion of tampon, horse riding, wearing tight clothes but especially by vaginal penetration $(3,4)$.

The ethiopathogenesis of LPV is not fully understood. Many factors such as genetics, hormonal factors and inflammation are found associated with the disease (5). Lymphocytic infiltration in the vestibular mucosa has been described $(6,7)$. However, the absence of classic active inflammation suggests the hypothesis of an excessive response and deregulated inflammation $(4,8,9)$.

A local inflammation mediated by increased inflammatory cytokine TNF- $\alpha$ was demonstrated in the vestibule of patients with LPV (10). Another study analyzing different immune cells in the vestibule showed a local immune activation: the formation of germinal centers with increased B lymphocytes density was found specific to LPV (4). In this study, the researchers looked for B lymphocytes and germinal centers in the vestibular mucosa and to assess if the local immune activation was observed in the patients.

\section{MATERIALS AND METHODS}

\section{Study subjects}

The study included 29 patients with LPV diagnosis and 20 age, sex and race-matched women with no history of vulvodynia. The archival vestibulectomy specimens of patients with LPV treated surgically in the gynecology clinic of Istanbul University, Istanbul Faculty of Medicine between 2009-2016 were used.

The inclusion criteria for LPV were: vulvar pain upon attempted vaginal intercourse or tampon insertion lasting more than one year; tenderness upon touch with a cotton tip in the vestibular area limited between Hart's line and hymen; failure of less than six months medical treatment (1-3). Exclusion criteria were: (1) use of antibiotics or immunosuppressive agents for the last 30 days; (2) clinically present microbial infection; (3) any neurologic disease or other pain syndrome (1-3).

Vestibular pain scores were obtained using a visual analog score ranging from 0 for no pain to 100 for severe intolerable pain: patients with LPV were asked to report the intensity of the pain they perceived while vestibular area was touched at 3, 5, 7 and 9 o'clock positions with a cotton tip. If the average of the 4 scores was higher than 36, surgical treatment (vestibulectomy) was offered to patients.

The control group involved age, sex and race-matched women who underwent posterior colporrhaphy for rectocele repair in the gynecology clinic of Istanbul University, Istanbul Faculty of Medicine between 2015-2016. The study was approved by the local ethical committee (Date: 12.09.2019, No: 80). All participants gave informed consent to participate in the study.

\section{Immunohistochemistry evaluation}

Tissues were fixed in 10\% formalin for 24 hours then embedded in paraffin. Cut into 3-5 $\mu \mathrm{m}$ sections, embedded paraffin tissue blocks were placed on microscope slides. The slides were incubated in $56^{\circ} \mathrm{C}$ for one night to dry out the sections. Sections were deparaffinized with $x y-$ lene solution for 30 minutes, immersed in acetone for 5 minutes and in $96 \%$ ethanol for 15 minutes, then washed with distilled water. Afterwards, to block the endogenous peroxidase activity, sections were incubated in 3\% hydrogen peroxide solution in methanol at room temperature for 10 minutes.

Once the sections were ready for immunohistochemical staining, incubation with antibodies against CD20 for B cells (clone 760-2531,1:1000; Ventana Medical Systems Roche Group, USA) were performed according to the manufacturers' instructions. The sections were subsequently incubated with anti-mouse antibody followed by exposure to streptavidin, horseradish peroxidase (HRP) conjugate. Then, 3-amino-9-ethylcarbazole (AEC) was added as substrate. Finally, all sections were counterstained with hematoxylin. All the procedures were performed in the immunochemistry laboratory of the Pathology Department of the Istanbul University School of Medicine.

\section{Tissue analyses}

The immunohistochemical scoring was done under light microscope at $\times 40$ magnification (Nikon Eclipse E800). Antigen stainings were assessed for density and localization in the vestibular mucosa. The evaluation was performed by taking the mean number of positive cells observed per field from 2-4 high-power fields (hpf). The number of germinal centers formed by $B$ cells in the sections were also counted.

\section{Statistical analysis}

The SPSS 20 software (IBM Corp, Armonk, NY) was used for statistical analyses. In addition to descriptive analysis, the Mann Whitney $U$ test was used for the comparison between patient and controls. A $p$ value of $<0.05$ was considered statistically significant. 


\section{RESULTS}

All subjects were Caucasian, from low-middle class and age, sex and race-matched. There were no statistical differences in the demographic findings of the two study groups.

CD20 is a marker of B lymphocyte appearing in the pre$\mathrm{B}$-cell stage and disappearing with differentiation to plasma cells (11). Anti-CD20 antibodies showed the presence of $B$ lymphocytes. When compared with the sections of controls, the researchers observed that B lymphocytes are statistically significantly higher in patients with LPV (Table 1). B lymphocytes were observed mostly in the stromal tissue of the mucosa (Figure 1).

The presence of germinal centers formed by B lymphocytes was observed only in patients with LPV (Figure 2). The number of germinal centers varied between 1-2 in 8 sections ( $27 \%$ of patients with LPV) (Table 1 ).

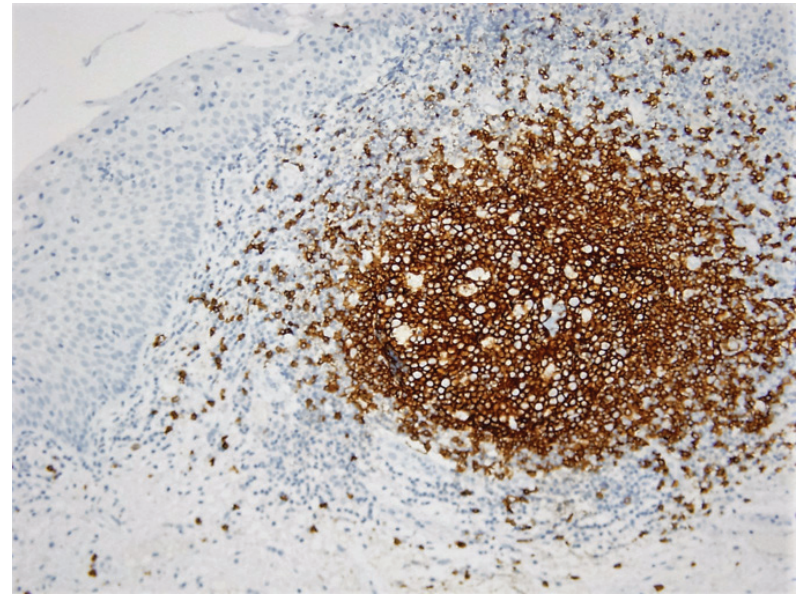

Figure 2: Germinal center in vulvar vestibular mucosa

A germinal center, formed by CD20+ immunostained B lymphocytes, in the sample of a patient with localized provoked vulvodynia. Histological sections were counterstained with hematoxylin and photomicrographed using $\times 20$ objective.

Table 1: The numbers of B lymphocytes and germinal centers in localized provoked vulvodynia

\begin{tabular}{|c|c|c|c|}
\hline CellType & $\begin{array}{c}\text { LPV }(n=29) \\
\text { Mean }(95 \% \mathrm{CI})^{\text {a }}\end{array}$ & $\begin{array}{l}\text { Controls }(n=20) \\
\text { Mean }(95 \% \mathrm{Cl})^{\mathrm{a}}\end{array}$ & $p$ value $^{b}$ \\
\hline B lymphocytes & 87 (58-129) & $21(12-32)$ & $<0.001$ \\
\hline Germinal centers & $0.31(0-2)$ & $0(0)$ & 0.011 \\
\hline
\end{tabular}

LPV: localized provoked vulvodynia, Cl: confidence interval, a: Mean is obtained with cell counts per microscopy field, analyzed from 2-4 fields ( $\times 40$ objective), b: Mann-Whitney $U$ test

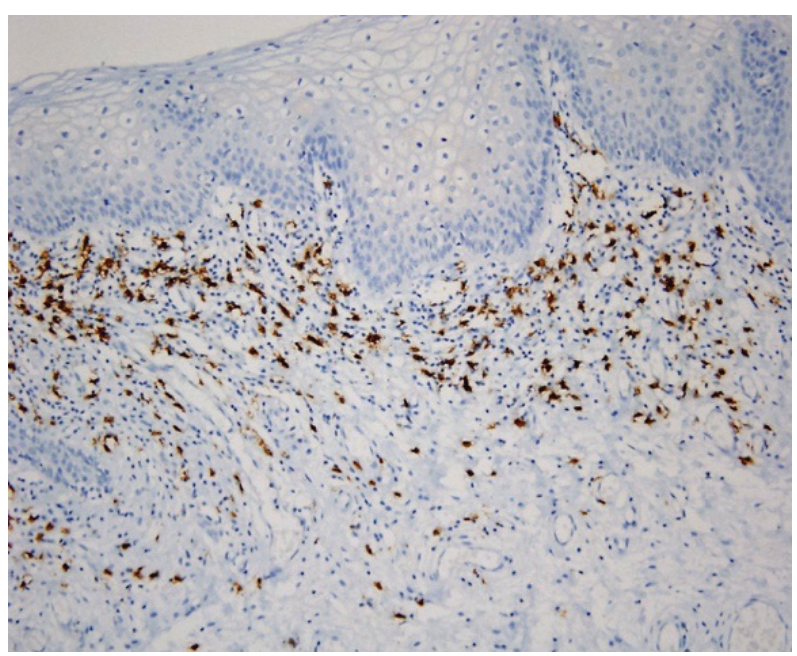

Figure 1: $\mathrm{CD} 20(+) \mathrm{B}$ lymphocytes in vulvar vestibular mucosa

Increased density of CD20+ B lymphocytes in a patient with localized provoked vulvodynia.

B lymphocytes were mostly observed mostly in the stromal tissue of the mucosa. Histological sections were counterstained with hematoxylin and photomicrographed using $\times 20$ objective.

\section{DISCUSSION}

This study is the first to assess local immune activation in the vestibulum of Turkish patients with LPV. The researchers observed significantly increased $B$ lymphocytes in patients with LPV. The germinal centers were observed only in patients with LPV. In a previous study conducted on Finnish women, the comparison of vestibulectomy specimens between women with LPV and controls showed statistically significantly increased B lymphocytes in the vestibule of patients with LPV. The presence of germinal centers was also observed only in patients with LPV, like our results (4).

B lymphocytes are cells that recognize specific antigens via different immunoglobulins (lg) anchored on the cell surface (12). Once a B lymphocyte recognizes an antigen, it differentiates into plasma cells that can secrete antibodies. Germinal centers are the microstructures where memory B cells and high-affinity antibodies secreting plasma cells are localized. It is important as it provides protection against reinfection (13). Recently, it was suggested that the germinal center response is the main pathway leading to autoantibodies found in autoimmune 
diseases (14). Therefore, the germinal center response requires a very delicate balance and complex regulation to avoid the development of autoreactive B cell clones and subsequent autoimmunity (13).

The presence of germinal centers with increased B lymphocytes density in the vestibule of patients with LPV suggests a local immune activation. An 'unknown antigen' captured by B lymphocytes activated the humoral immunity and a germinal center response was given by the lymphoid tissue localized in the vestibule. Each time the vestibular mucosa is exposed to the 'unknown antigen', this cycle is triggered leading to a local inflammation in the vestibular mucosa, a feature demonstrated by previous studies (6). A constant exposure to the 'unknown antigen' contributes to the chronic persistence of the disease and the mainstay of the therapy will be avoiding the 'unknown antigen'.

A different perspective can be adopted for the ethiopathogenesis of LPV: an abnormal germinal center response following a single exposure of an 'unknown antigen' can be the starting point in LPV. The differentiation of B lymphocytes in the germinal centers can be unsuccessful if autoreactive $B$ cells are developed in the end of this mutation process (13). Normally, the self-tolerance mechanisms in the germinal centers prevent the autoantibody production from these autoreactive B cells (15). However, an abnormal germinal center response with deficient self-tolerance mechanisms can't block this process and autoimmunity will subsequently develop. The increased B lymphocyte density found in the vestibule can in fact point out these autoreactive $B$ cells clones. As the production of autoantibodies from these autoreactive B cells are found associated with autoimmune disease, LPV can potentially emerge as an autoimmune disease of the vestibule (15).

The main strength of the study is the high number of women involved in both patient $(n=29)$ and control $(n=20)$ groups. All specimens in the patient groups were obtained by the same surgeon, all specimens in the study were pathologically examined by one physician, making any inter-observer variation unlikely. The main limitation of the study is that any other autoimmunity antibodies were not assessed in both groups to support a stronger association between LPV and autoimmunity.

\section{CONCLUSION}

Localized provoked vulvodynia remains a disease where more studies are needed to understand its pathophysiology. The 'agent' triggering the activation of VALT is not elucidated. The presence of germinal centers with increased B lymphocytes density underlines a local immune activation in the vestibule of patients with LPV. An abnormal germinal center response can trigger the pathway to the development of autoimmunity through the emergence of autoreactive B cells clone and autoantibodies. The hypothesis of LPV being an autoimmune disease of the vestibule can be the subject of more studies that can reveal interesting findings. Hopefully, a better understanding of the disease will help in developing targeted therapeutics for LPV.

Informed Consent: Written consent was obtained from the participants.

Ethics Committee Approval: This study was approved by the Clinical Research Ethical Committee of the Istanbul University, Istanbul Faculty of Medicine (Date: 26.02.2016, No: 290).

Peer Review: Externally peer-reviewed.

Author Contributions: Conception/Design of Study- i.D.K., S.E.A.; Data Acquisition- I.D.K., C.Y., S.E.A.; Data Analysis/Interpretation- I.D.K., S.Ö., E.Y.,S..; Drafting Manuscript- I.D.K., S.E.A.; Critical Revision of Manuscript- C.Y., S.Ö., E.Y., S.T., S.E.A.; Approval and Accountability- I.D.K., C.Y., S.Ö., E.Y., S.T., S.E.A.

Conflict of Interest: Authors declared no conflict of interest

Financial Disclosure: Authors declared no financial support.

\section{REFERENCES}

1. Moyal-Barracco M, Lynch PJ. 2003 ISSVD terminology and classification of vulvodynia: a historical perspective. J Reprod Med 2004;49(10):772-7.

2. Friedrich EG, Jr. Vulvar vestibulitis syndrome. J Reprod Med 1987;32(2):110-4.

3. Goetsch MF. Vulvar vestibulitis: prevalence and historic features in a general gynecologic practice population. Am J Obstet Gynecol 1991;164(6 Pt 1):1609-16. [CrossRef]

4. Tommola P, Butzow R, Unkila-Kallio L, Paavonen J, Meri S. Activation of vestibule-associated lymphoid tissue in localized provoked vulvodynia. Am J Obstet Gynecol 2015;212(4):476.e1-8. [CrossRef]

5. Bornstein J, Goldstein AT, Stockdale CK, Bergeron S, Pukall C, Zolnoun D, et al. 2015 ISSVD, ISSWSH, and IPPS Consensus Terminology and Classification of Persistent Vulvar Pain and Vulvodynia. J Low Genit Tract Dis 2016;20(2):126-30. [CrossRef]

6. Pyka RE, Wilkinson EJ, Friedrich EG, Jr., Croker BP. The histopathology of vulvar vestibulitis syndrome. Int J Gynecol Pathol 1988;7(3):249-57. [CrossRef]

7. Goetsch MF, Morgan TK, Korcheva VB, Li H, Peters D, Leclair CM. Histologic and receptor analysis of primary and secondary vestibulodynia and controls: a prospective study. Am J Obstet Gynecol 2010;202(6):614 e1-8. [CrossRef]

8. Bohm-Starke N, Falconer C, Rylander E, Hilliges M. The expression of cyclooxygenase 2 and inducible nitric oxide synthase indicates no active inflammation in vulvar vestibulitis. Acta Obstet Gynecol Scand 2001;80(7):638-44. [CrossRef]

9. Eva LJ, Rolfe KJ, MacLean AB, Reid WM, Fong AC, Crow $J$, et al. Is localized, provoked vulvodynia an inflammatory condition? J Reprod Med 2007;52(5):379-84. 
10. Seckin-Alac E, Akhant SE, Bastu E, Tuzlalik S, Yavuz E. Elevated tissue levels of tumor necrosis factor-alpha in vulvar vestibulitis syndrome. Clin Exp Obstet Gynecol 2014;41(6):691-3.

11. Pavlasova G, Mraz M. The regulation and function of CD20: an "enigma" of B-cell biology and targeted therapy. Haematologica 2020;105(6):1494-506. [CrossRef]

12. LeBien TW, Tedder TF. B lymphocytes: how they develop and function. Blood 2008;112(5):1570-80. [CrossRef]
13. Stebegg M, Kumar SD, Silva-Cayetano A, Fonseca VR, Linterman MA, Graca L. Regulation of the Germinal Center Response Front Immunol 2018;9:2469. [CrossRef]

14. DeFranco AL. Germinal centers and autoimmune disease in humans and mice. Immunol Cell Biol 2016;94(10):918-24. [CrossRef]

15. Young C, Brink R. Germinal centers and autoantibodies. Immunol Cell Biol 2020;98(6):480-9. [CrossRef] 